\title{
Impact of process conditions on the density and durability of wheat, oat, canola, and barley straw briquettes
}

\author{
J. S. Tumuluru • L. G. Tabil • Y. Song • K. L. Iroba • \\ V. Meda
}

Published online: 10 September 2014

(C) The Author(s) 2014. This article is published with open access at Springerlink.com

\begin{abstract}
The present study is to understand the impact of process conditions on the quality attributes of wheat oat, barley, and canola straw briquettes. Analysis of variance indicated that briquette moisture content and initial density immediately after compaction and final density after 2 weeks of storage are strong functions of feedstock moisture content and compression pressure, whereas durability rating is influenced by die temperature and feedstock moisture content. Briquettes produced at a low feedstock moisture content of $9 \%$ (w.b.) yielded maximum densities $>700 \mathrm{~kg} / \mathrm{m}^{3}$ for wheat, oat, canola, and barley straws. Lower feedstock moisture content of $<10 \%$ (w.b.) and higher die temperatures $>110{ }^{\circ} \mathrm{C}$ and compression pressure $>10 \mathrm{MPa}$ minimized the briquette moisture content and maximized densities and durability rating based on surface plots observations. Optimal process conditions indicated that a low feedstock moisture content of about $9 \%$ (w.b.), high die temperature of $120-130{ }^{\circ} \mathrm{C}$, medium-to-large hammer mill screen sizes of about 24 to $31.75 \mathrm{~mm}$, and low to high compression pressures of 7.5 to $12.5 \mathrm{MPa}$ minimized briquette moisture content to $<8 \%$ (w.b.) and maximized density to $>700 \mathrm{~kg} / \mathrm{m}^{3}$. Durability rating $>90 \%$ is achievable at higher die temperatures of $>123{ }^{\circ} \mathrm{C}$, lower to medium feedstock moisture contents of 9 to $12 \%$ (w.b.), low to high compression pressures of 7.5 to $12.5 \mathrm{MPa}$, and large hammer
\end{abstract}

J. S. Tumuluru $(\bowtie)$

Biofuels and Renewable Energy Technologies Department, Energy

Systems and Technologies Division, Idaho National Laboratory,

P.O. Box 1625, Idaho Falls, ID 83415-2025, USA

e-mail: jayashankar.tumuluru@inl.gov

L. G. Tabil $\cdot$ K. L. Iroba $\cdot$ V. Meda

Department of Chemical and Biological Engineering, University of

Saskatchewan, Saskatoon, SK, Canada S7N 5A9

Y. Song

College of Engineering, Shenyang Agricultural University,

Shenyang, China mill screen size of $31.75 \mathrm{~mm}$, except for canola where a lower compression pressure of 7.5 to $8.5 \mathrm{MPa}$ and a smaller hammer mill screen size of $19 \mathrm{~mm}$ for oat maximized the durability rating values.

Keywords Agricultural straws · Briquettes · Unit density · Durability rating $\cdot$ Response surface models $\cdot$ Optimization . Genetic algorithm

\section{Introduction}

Lignocellulosic biomass includes agricultural residues, hardwood, and softwood, as well as dedicated biomass crops. According to Kim and Dale [1], the estimated residue from crops such as corn, wheat, oats, rice, sorghum, and sugarcane throughout the world is approximately 1.5 billion metric tonnes. These residues also constitute one of the most important biomass feedstocks in Canada due to its vast agricultural base. Major cereal crops (such as wheat, barley, and oats) are grown on the Canadian prairies. The total straw available for industrial use after soil and livestock requirements is approximately $15 \mathrm{Mt}$ [2]. The Saskatchewan Ministry of Agriculture reported that the province of Saskatchewan alone produced 12.44 Mt of wheat, $5.63 \mathrm{Mt}$ of canola, $4.59 \mathrm{Mt}$ of barley, and $2.3 \mathrm{Mt}$ of oats straws. This abundant, inexpensive, and readily available biomass source indicates that Canada can play a significant role in the development of an environmentally benign bioenergy sector.

Agricultural biomass, due to its low density limitations, must be processed and handled in an efficient manner to enhance its flowability, reduce material waste, and increase its bulk density to reduce transportations costs. The densification of biomass involves the compression or compaction of biomass to eliminate inter- or intraparticle voids. Different densification technologies are available for 
producing a uniform feedstock commodity for bioenergy applications [3]. Among these technologies, pelleting and briquetting are the two most widely used. Briquetting has advantages over pelleting in terms of feedstock process variables such as particle size, where bigger particle sizes can be used. In general, briquettes produced using a hydraulic press have uniform shape and size, typically $40 \times 40$-mm cylinders, and unit densities of about $700-800 \mathrm{~kg} / \mathrm{m}^{3}$. The quality of briquettes or pellets can be managed by proper control of process and feedstock conditions, formulation, and use of additives. A number of researchers have discussed in detail how process variables (i.e., die temperature, compression pressure, die geometry, and retention time), feedstock variables (i.e., moisture content and particle size and shape), and biomass composition (i.e., protein, fat, cellulose, hemicelluloses lignin, etc.) play a major role in densified biomass quality [3-13]. Pelleting at high die temperatures can result in plasticization of components like protein and starch, and softening of lignin [14]. Starch, if present in biomass, gelatinizes and lignin undergoes softening due to temperature and pressure and helps in biomass binding [15]. Also, the pressure applied can result in crushing of biomass particles, thus opening up the cell structure and exposing the protein and pectin, which can act as a natural binder. Feedstock moisture content is considered an important process variable as it impacts the physical properties of briquettes produced [9]. Low-moisture, chopped corn stover (5 to $10 \%$, w.b.) resulted in more dense, stable, and durable briquettes than high-moisture stover $(15 \%$ w.b.) [16]. Grover and Mishra [8] indicated that agricultural materials can be briquetted even at $22 \%$ (w.b.) feedstock moisture content. During briquetting, the moisture in the material forms steam under high compression pressure, hydrolyzing the hemicellulose and lignin into lower molecular carbohydrates, lignin products, sugar polymers, and other derivatives which act as adhesives and bind the particles together [8]. The same authors indicated that a briquette press is more flexible in terms of particle size where bigger particles are suitable as bonding is more due to interlocking of biomass particles. In general, briquetting or cubing may require coarse grinding or one-stage particle size reduction, whereas pelletizing requires two or more stage particle size reduction, making for a lower energy requirement of the process. Kaliyan and Morey [6,7] and Adapa et al. [10] investigated the effects of particle size on the densification characteristics of corn stover, switchgrass, and alfalfa and concluded that decreasing the geometric mean particle size helps to increase the density of densified biomass.

In most of the earlier studies, researchers have used particle sizes of $<19 \mathrm{~mm}$ in combination with other process variables [16-18] for briquetting of agricultural and woody biomass. The objective of the present research is to understand how bigger particles sizes produced using larger hammer mill screens of $>19 \mathrm{~mm}$ in combination with other process variables influence the quality of the briquettes produced. Also, making briquettes using bigger particle sizes can eliminate more than two-stage grinding (which is typically used to grind biomass to smaller particle sizes), and can reduce the overall briquette production cost. The specific objective of this present study is to investigate the effect of larger hammer mill screen size in the range of 19.1 to $31.75 \mathrm{~mm}$, compression pressure in the range of 7.5 to $12.5 \mathrm{MPa}$, feedstock moisture content in the range of 9 to $15 \%$ (w.b.), and die temperature in the range of 90 to $130{ }^{\circ} \mathrm{C}$ on briquette physical quality attributes, such as moisture content, unit density immediately after compaction (density-1), unit density after 2 weeks of storage (density-2), and durability rating (DR).

\section{Materials and Methods}

\section{Feedstocks}

Four types of agricultural biomass residues (i.e., barley, canola, oat, and wheat straws) were collected from a farmer in the Central Butte area of Saskatchewan, Canada in September 2008 in the form of bales typically having dimensions of $0.45 \times 0.35 \times 1.00 \mathrm{~m}$ [12]. Adapa et al. [12] used these straws in their composition investigation (shown in Table 1). Table 1 indicates that the composition of agricultural straws varies with feedstock variety. The straw samples were ground initially using a chopper (fabricated by Bioprocessing Lab, Department of Agricultural and Bioresource Engineering, University of Saskatchewan [20]) with no screens and further ground using a hammer mill (Serial no. 6 M13688; Glen Mills Inc., Maywood, NJ) using screen openings of 19.1, 25.4, and $31.75 \mathrm{~mm}$ [20]. The ground straw samples were further used for briquetting studies. Each of these ground straw samples were conditioned to a moisture content of 9,12 , and $15 \%$

Table 1 Chemical composition of barley, wheat, oat, and canola straws [12]

\begin{tabular}{lrrrr}
\hline Composition $\left(\% \mathrm{DM}^{\mathrm{a}}\right)$ & Barley & Canola & Oat & Wheat \\
\hline Protein & 3.62 & 6.53 & 5.34 & 2.33 \\
Fat & 1.91 & 0.69 & 1.65 & 1.59 \\
Starch & 0.11 & 0.34 & 0.12 & 2.58 \\
Lignin & 17.13 & 14.15 & 12.85 & 13.88 \\
Cellulose $^{\mathrm{b}}$ & 33.25 & 42.39 & 37.60 & 34.20 \\
Hemicellulose $^{\mathrm{c}}$ & 20.36 & 16.41 & 23.34 & 23.68 \\
Ash & 2.18 & 2.10 & 2.19 & 2.36 \\
\hline
\end{tabular}

${ }^{\text {a }} D M$ dry matter

${ }^{\mathrm{b}}$ Cellulose percentage is calculated indirectly from percentage ADF and lignin (\%ADF -\%lignin) [19]

${ }^{\mathrm{c}}$ Hemicellulose percentage is calculated indirectly from percentage NDF and ADF (\%NDF-\%ADF) [19] 
(w.b.), respectively, placed in Ziploc bags and stored in control storage set at $4{ }^{\circ} \mathrm{C}$ (52\% relative humidity). The moisture content of the straw samples was determined using ASABE standard S358.2 [21].

\section{Experimental Plan}

In order to investigate the effects of process variables on physical quality attributes (feedstock moisture content, density immediately after compaction (density-1) and after 2 weeks of storage (density-2), and durability rating (DR) of biomass briquette), experiments were designed at three levels of compression pressure $(7.5,10$, and $12.5 \mathrm{MPa})$, die temperature $\left(90,110\right.$, and $\left.130^{\circ} \mathrm{C}\right)$, feedstock moisture content (i.e., 9, 12, $15 \%$, w.b.), and hammer mill screen size (19.05, 25.4, and $31.75 \mathrm{~mm}$ ), while keeping the retention time of chopped biomass in the die for $30 \pm 2 \mathrm{~s}$. Table 2 indicates the actual and coded levels of the variables selected based on BoxBehnken experimental design. Combination of the four independent variables at three levels yielded 27 experimental combinations that were repeated ten times. Using the four ground biomass samples (canola, barley, wheat, and oat), 1,080 experimental briquetting runs in total were conducted.

\section{Hydraulic Briquette Press}

A laboratory hydraulic press (Model 10HP, Serial A4569, Curtis Hoover Ltd., Edmonton, Alberta, Canada) reported by Mani et al. [16] was used in the briquetting experiments of the selected agricultural biomass residues (Fig. 1). The press consisted of an upper and lower hydraulic-driven ram moving inside an electrically heated die. This briquetting machine has a cylindrical die, an upper ram that moves down through die, and a lower ram that is held in place and acts as support. The die is connected to a heater that heats the chopped biomass to be compacted. Six type "T" thermocouples were installed on the die to measure and control its temperature. Five out of the six thermocouples were connected to the data acquisition system, while the sixth one was connected to a heater with temperature controller (Chromalox Temperature Control, Cat. No. AR-5529 [Edwin L. Wiegan Co., Pittsburgh, PA]). The

Table 2 Actual and coded levels of briquetting process conditions

\begin{tabular}{lllll}
\hline Independent variables & Code & \multicolumn{3}{l}{ Coded levels } \\
\cline { 3 - 5 } & & -1 & 0 & 1 \\
\hline Die temperature $\left({ }^{\circ} \mathrm{C}\right)$ & $x_{1}$ & 90 & 110 & 130 \\
Feedstock moisture content $(\%)$ & $x_{2}$ & 9 & 12 & 15 \\
Compression pressure $(\mathrm{MPa})$ & $x_{3}$ & 7.5 & 10 & 12.5 \\
Hammer mill screen size $(\mathrm{mm})$ & $x_{4}$ & 19.1 & 25.4 & 31.75 \\
\hline
\end{tabular}

die diameter was about $30 \mathrm{~mm}$; the length of the briquette varied depending on the mass of the feed material and compression pressure used for briquetting. Two pressure transducers, one measuring the top hydraulic-driven ram (upper ram) (Daytronic Model 502-30000 (range 0-3000 psig), Daytronic, Dayton, $\mathrm{OH}$ ) and the other measuring the bottom hydraulic-driven ram (lower ram) (Schaevitz, Model P10210005 (range 0-3,500 psig), Schaevitz, Hampton, VA) were used. Both pressure transducers were calibrated to measure compression pressures in the range of $0-17.24 \mathrm{MPa}(0-$ 2,500 psi). The amplifier linked to the compartment is used to get an output voltage in the range of $0-5 \mathrm{~V}$. The amplifier produces $1 \mathrm{~V}$ for each $3.45 \mathrm{MPa}$ (500 psi). A displacement transducer was used to measure the upper ram displacement.

\section{Briquetting Process}

Figure 2 indicates the process flow diagram for making briquettes using agricultural straws. The agricultural straws were initially chopped and later ground using a hammer mill. Tumuluru et al. [20] has discussed, in detail, the chopper and hammer mill used for grinding of the agricultural straws used in the present briquetting study. The moisture content of the ground biomass was further adjusted to the desired levels per experimental design. The mass of moisture adjusted straw samples used for making briquettes was $10 \pm 0.05 \mathrm{~g}$. Three preset loads of 5,298, 7,065, and 8,831 N (corresponding to compression pressures of $7.5,10$, and $12.5 \mathrm{MPa}$, respectively) were used to compress the samples in the die. The lower ram, when held in place, acts as support and does not move down before ejection. The upper ram was moved at a speed of $0.04 \mathrm{~m} / \mathrm{s}$; once the desired preset load was attained, the upper ram was retained in place for $30 \pm 2 \mathrm{~s}$ in order to avoid a spring-back of the compressed biomass. The compression pressure of the upper ram was greater than the lower ram during residence time because there are other forces involved, such as frictional force to extrude the briquette. The ejection speed used was $0.013 \mathrm{~m} / \mathrm{s}$. Thereafter, the briquette was ejected out of the barrel by moving down the upper and lower rams. Ten briquette replicates were made using each of the treatment combinations. After compression, the dimensions (i.e., height and diameter) and mass of all of the briquettes were measured to determine the initial unit density (density-1). Samples were then stored for 2 weeks in Ziploc bags at room temperature of $20{ }^{\circ} \mathrm{C}$. This storage period will allow the briquettes to reach a final unit density with greater dimensional stability. After 2 weeks of storage, the briquettes were further evaluated for briquette moisture content, final unit density (density-2), and durability rating. 
Fig. 1 Laboratory-scale briquette press

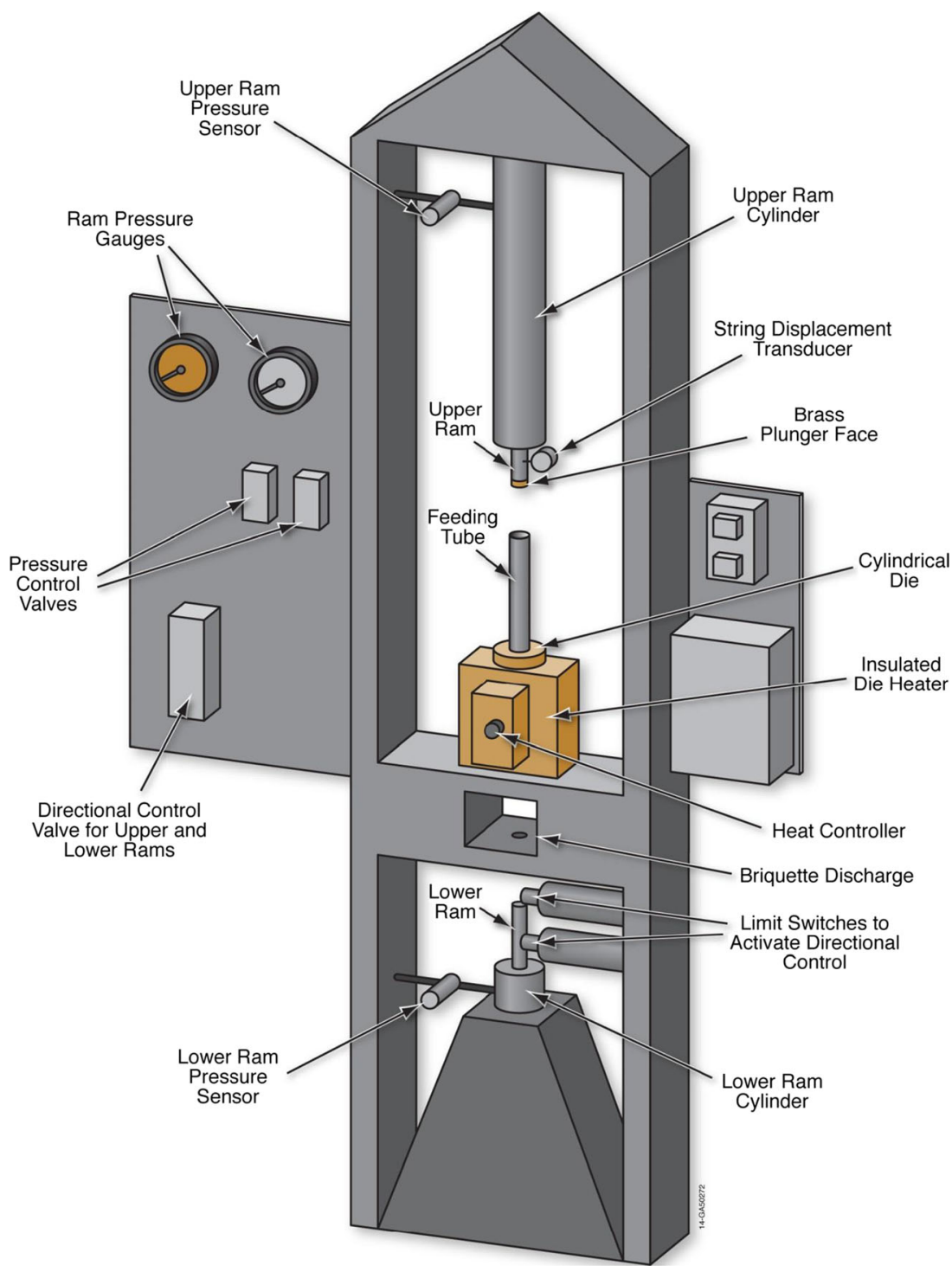

Physical Quality Attributes

The unit densities of each of the briquette samples immediately after compaction (density-1) and after 2 weeks of storage (density-2) were calculated based on ASABE Standard S269.4 [22] by direct measurement. Durability rating (DR) and briquette moisture content were measured after 2 weeks of storage. The briquette moisture content after the durability test was determined based on ASABE Standard S358.2 [21]. Durability rating (DR) represents the measure of shear and impact forces that briquettes could withstand in the course of handling, storage, and transportation processes [6, 12, 23]. The briquette DR was tested based on ASABE Standard S269.4 [22] by tumbling ten briquettes (representing the ten replicates of each combination) in a tumbling durability tester for $3 \mathrm{~min}$ at $40 \mathrm{rpm}$. According to this procedure, for particles with a mass of more than $20 \%$, the average original particle mass are designated "CSM" (cube size material). If a sample does not produce any CSM in the output sample, the durability rating is zero.

\section{Experimental Data Analysis}

In general, response surface models are used in process and product development in chemical and biological engineering problems [24, 25]. A second-order response surface model was developed for the briquetting process variables like die temperature $\left(\mathrm{x}_{1}\right)$, feedstock moisture content $\left(\mathrm{x}_{2}\right)$, compression pressure $\left(\mathrm{x}_{3}\right)$, and hammer mill screen size $\left(\mathrm{x}_{4}\right)$. Equation 1 indicates the response surface model developed for briquette quality attributes like briquette moisture content, unit density immediately after compaction (density-1), unit density after 2 weeks of storage (density-2), and durability rating (DR). 


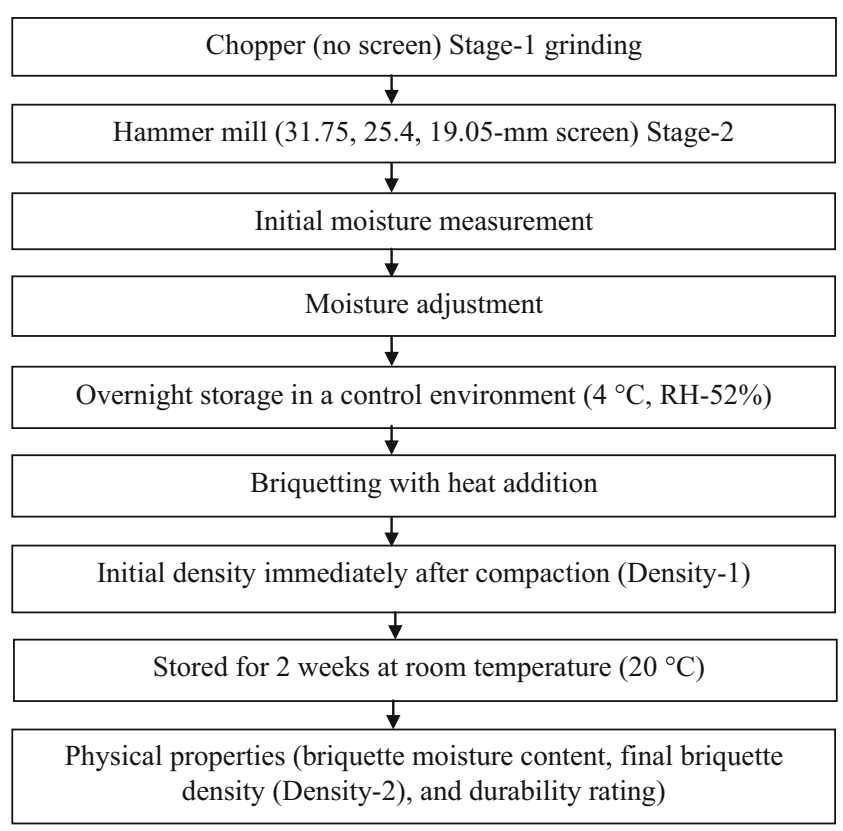

Fig. 2 Process flow chart for briquetting of agricultural straws

$$
y=b 0+\sum_{i=1}^{n} b_{\mathrm{i}} x_{\mathrm{i}}+\sum_{i=1}^{n} b_{\mathrm{ii}} x_{\mathrm{i}}^{2}+\sum_{i=1}^{n} \sum_{j=1}^{n} b_{\mathrm{ij}} x_{\mathrm{i}} x_{\mathrm{j}}+\varepsilon
$$

where $y$ is the dependent variable (observed); $x_{\mathrm{i}}$ and $x_{\mathrm{j}}$ are the coded independent variables; $b_{0}, b_{\mathrm{i}}$, and $b_{\mathrm{j}}$ are coefficients; $n$ is the number of independent variables; and $\in$ is a random error [26]. Statistica [27], a statistical software, was used to develop the response surface models. Analysis of variance (ANOVA) which is used to examine the difference between group means for full second-order response surface model, and was used to understand the statistical significance of linear, quadratic, and interactive effect of process variables [27]. Major limitations of response surface methodology (RSM) to optimize a process accurately when the system is complex and has a high degree of interaction between process variables.

Optimization using evolutionary algorithms like genetic algorithm (GA), which are computational methods, are gaining importance to solve complex processes. GAs are adaptive heuristic search algorithms that mimic the processes of biological evolution [28-31]. GAs have been successfully used for highly complex and nonlinear systems where the objective is to either maximize or minimize function [28, 30]. Shankar and Bandyopadhyay [32], Shankar et al. [33], and Tumuluru et al. [34] successfully used GA to optimize the extrusion process conditions for physical properties, volumetric flow rates, and proximate composition of the extrudates during single screw extrusion. In the present study, the GA software developed by Shankar and Bandyopadhyay [32], and
Shankar et al. [33] in $\mathrm{C}$ and $\mathrm{VC}++$ language was used. Response surface models developed for the briquette quality attributes were used as the objective functions to find the optimum process conditions which can minimize briquette moisture content and maximize density1 , density-2, and DR. In the present problem, a fixed population of 100 , fixed number of iterations of 100 (which is the stopping criteria of the algorithm), and crossover and mutation probabilities of 0.98 and 0.02 were used [34].

\section{Results}

Tumuluru et al. [20] discussed in detail the densities of barley, wheat, canola, and oat straws ground using hammer mill fitted with screen sizes of 19.1, 25.4, and $31.75 \mathrm{~mm}$. The bulk densities of these ground straws samples were in the range of 36 to 67,37 to 58,48 to 58 , and 40 to $58 \mathrm{~kg} / \mathrm{m}^{3}$, respectively. Experimental results indicated that briquetting of these agricultural straw samples has increased the unit density by about 8-12 times at different briquetting process conditions (Table 3). The average briquette unit densities (density-1: immediately after compaction and density-2: after 2 weeks of storage), briquette moisture content, and durability rating (DR) values of barley, canola, oat, and wheat straw briquettes, based on Box-Behnken experimental design, are listed in Table 3. The combination of the four independent process variables (die temperature, compression pressure, hammer mill screen size, and feedstock moisture content) produced different quality briquettes. The standard deviation values observed for briquette moisture content and density- 1 and density-2 were in the range of 0.01 to $0.05 \%$ (w.b.) and 20 to $50 \mathrm{~kg} / \mathrm{m}^{3}$, for the four different feedstocks studied. The observed experimental results indicated that feedstock moisture content played a major role in the biomass briquetting process. Briquette densities decreased with increasing feedstock moisture content. Briquettes produced at a low feedstock moisture content of $<9 \%$ (w.b.) yielded the highest briquette unit densities $>700 \mathrm{~kg} / \mathrm{m}^{3}$ for all straw samples, whereas briquettes at $15 \%$ (w.b.) produced the lowest unit densities with more cracks observed on the surface. The change in briquette unit density after 2 weeks of storage for barley, canola, oat, and wheat straw briquettes were in the range of 1.3 to 9,0 to $2.7,0$ to 6.1 , and 0 to $11.4 \%$, respectively. The observed DR values were higher at a lower feedstock moisture content and higher die temperature. Figure 3 shows typical briquettes manufactured using canola, wheat, oat and barley straw samples. 
Table 3 Physical quality attributes of barley, canola, oat, and wheat straw briquettes based on Box-Behnken experimental design

\begin{tabular}{|c|c|c|c|c|c|c|c|c|c|c|c|c|c|c|c|c|c|c|c|c|}
\hline \multirow[t]{2}{*}{ E.N. } & \multicolumn{4}{|c|}{ Process conditions } & \multicolumn{4}{|c|}{ Barley } & \multicolumn{4}{|c|}{ Canola } & \multicolumn{4}{|l|}{ Oat } & \multicolumn{4}{|c|}{ Wheat } \\
\hline & $x_{1}$ & $x_{2}$ & $x_{3}$ & $x_{4}$ & D-1 & D-2 & $\mathrm{MC}$ & $\mathrm{DR}$ & D-1 & D-2 & $\mathrm{MC}$ & DR & D-1 & D-2 & $\mathrm{MC}$ & DR & D-1 & D-2 & $\mathrm{MC}$ & \\
\hline 1 & 0 & 0 & 0 & 0 & 595 & 570 & 8.33 & 88 & 636 & 628 & 11.3 & 87 & 589 & 566 & 9.7 & 84 & 572 & 565 & 10.1 & 89 \\
\hline 2 & -1 & 1 & 0 & 0 & 459 & 428 & 11.7 & 64 & 664 & 646 & 13.4 & 86 & 437 & 413 & 12.6 & 54 & 413 & 380 & 12.9 & 47 \\
\hline 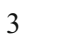 & 0 & 0 & 1 & -1 & 638 & 599 & 9.6 & 80 & 647 & 645 & 10.8 & 88 & 527 & 495 & 10.7 & 68 & 551 & 536 & 10.4 & 80 \\
\hline 4 & 1 & 0 & -1 & 0 & 555 & 539 & 10 & 82 & 627 & 632 & 10.9 & 94 & 555 & 583 & 9.7 & 89 & 565 & 557 & 10.2 & 92 \\
\hline 5 & 0 & 0 & 0 & 0 & 571 & 551 & 10.3 & 85 & 646 & 641 & 11.1 & 81 & 576 & 551 & 10.1 & 81 & 604 & 590 & 10.4 & 91 \\
\hline 6 & 0 & 0 & -1 & -1 & 590 & 568 & 10 & 89 & 602 & 603 & 11.1 & 89 & 600 & 492 & 10.1 & 84 & 521 & 510 & 10.6 & 93 \\
\hline 7 & -1 & 0 & 1 & 0 & 620 & 592 & 10.1 & 86 & 676 & 669 & 11.3 & 87 & 557 & 535 & 9.9 & 64 & 569 & 559 & 10.3 & 78 \\
\hline 8 & 1 & 0 & 0 & 1 & 636 & 614 & 9.3 & 92 & 696 & 704 & 10.2 & 95 & 506 & 490 & 10 & 88 & 604 & 596 & 10.4 & 94 \\
\hline 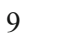 & 0 & 1 & 1 & 0 & 464 & 441 & 11.3 & 61 & 573 & 570 & 13 & 84 & 384 & 364 & 12.9 & 44 & 489 & 478 & 11.5 & 84 \\
\hline 0 & -1 & 0 & 0 & 1 & 615 & 588 & 9.7 & 86 & 723 & 715 & 11.1 & 93 & 525 & 504 & 10.3 & 8 & 591 & 569 & 10.2 & 66 \\
\hline 11 & 0 & 0 & 1 & 1 & 640 & 621 & 9.7 & 88 & 724 & 722 & 10.6 & 91 & 548 & 524 & 10.3 & 87 & 598 & 585 & 10 & 92 \\
\hline 12 & -1 & -1 & 0 & 0 & 685 & 659 & 8.3 & 85 & 710 & 704 & 8.2 & 90 & 605 & 576 & 9.0 & 78 & 592 & 571 & 8.2 & 71 \\
\hline 13 & -1 & 0 & -1 & 0 & 608 & 578 & 10.6 & 87 & 631 & 623 & 11.3 & 87 & 525 & 493 & 9.6 & 71 & 559 & 549 & 10.2 & 81 \\
\hline 14 & 0 & -1 & 0 & -1 & 683 & 665 & 8.1 & 87 & 684 & 680 & 8.3 & 89 & 662 & 636 & 8.0 & 87 & 600 & 587 & 3.7 & 87 \\
\hline 15 & 0 & -1 & 0 & 1 & 729 & 719 & 7.3 & 90 & 747 & 743 & 8.3 & 84 & 658 & 645 & 8.0 & 91 & 788 & 698 & 8.1 & 94 \\
\hline 16 & 0 & 0 & 0 & 0 & 589 & 572 & 10.2 & 89 & 657 & 652 & 11.4 & 90 & 575 & 553 & 10 & 83 & 619 & 610 & 10.1 & 92 \\
\hline 17 & 1 & -1 & 0 & 0 & 715 & 698 & 7.5 & 91 & 743 & 743 & 8.0 & 95 & 666 & 647 & 7.8 & 90 & 666 & 657 & 8.4 & 92 \\
\hline 18 & 1 & 0 & 0 & -1 & 615 & 588 & 10.1 & 87 & 677 & 673 & 11.1 & 94 & 516 & 501 & 9.8 & 82 & 518 & 508 & 11.2 & 88 \\
\hline 19 & -1 & 0 & 0 & -1 & 581 & 546 & 10.8 & 69 & 664 & 656 & 11.4 & 89 & 541 & 511 & 10.4 & 65 & 495 & 473 & 10.9 & 90 \\
\hline 20 & 0 & 1 & 0 & -1 & 402 & 380 & 12.1 & 42 & 558 & 554 & 12.9 & 73 & 410 & 397 & 12 & 47 & 375 & 353 & 11.4 & 58 \\
\hline 21 & 0 & 0 & -1 & 1 & 629 & 614 & 9.6 & 91 & 670 & 666 & 10.6 & 93 & 513 & 500 & 9.7 & 88 & 571 & 553 & 10.2 & 91 \\
\hline 22 & 0 & -1 & -1 & 0 & 660 & 638 & 8.3 & 88 & 581 & 579 & 8.5 & 93 & 656 & 633 & 7.6 & 89 & 599 & 594 & 8.3 & 87 \\
\hline 23 & 1 & 0 & 1 & 0 & 608 & 590 & 9.8 & 90 & 678 & 677 & 11.2 & 92 & 538 & 525 & 10 & 81 & 574 & 577 & 9.6 & 95 \\
\hline 24 & 0 & -1 & 1 & 0 & 705 & 687 & 8.1 & 89 & 726 & 726 & 8.4 & 91 & 714 & 700 & 7.3 & 86 & 657 & 643 & 8.6 & 89 \\
\hline 25 & 0 & 1 & -1 & 0 & 447 & 425 & 12.4 & 73 & 563 & 561 & 12.8 & 90 & 408 & 383 & 11.2 & 67 & 380 & 370 & 12.3 & 68 \\
\hline 26 & 1 & 1 & 0 & 0 & 455 & 433 & 11.6 & 73 & 587 & 587 & 12.9 & 92 & 366 & 351 & 11.6 & 56 & 359 & 352 & 12 & 78 \\
\hline 27 & 0 & 1 & 0 & 1 & 475 & 432 & 12.3 & 71 & 579 & 573 & 13 & 91 & 413 & 393 & 11.8 & 71 & 408 & 395 & 12.6 & 88 \\
\hline
\end{tabular}

E.N experiment number, D-1 (density-1): average density $\left(\mathrm{kg} / \mathrm{m}^{3}\right)$ of briquettes immediately after compaction $(n=10)$; D-2 (density-2): average density $\left(\mathrm{kg} / \mathrm{m}^{3}\right)$ of briquettes after 2 weeks of storage $(n=10) ; M C$ average briquette moisture content (\% w.b.) after 2 weeks of storage $(n=10), D R$ durability rating after 2 weeks of storage

$x_{1}$ Die temperature $\left({ }^{\circ} \mathrm{C}\right), x_{2}$ feedstock moisture content (\%, w.b.), $x_{3}$ compression pressure (MPa), $x_{4}$ screen size (mm) of the hammer mill used to grind the biomass

\section{Response Surface Analysis}

Regression equations developed for the physical quality attributes of the briquettes (briquette moisture content, initial unit density immediately after compaction (density-1), final unit density after 2 weeks of storage (density-2), and durability rating (DR)) in terms of die temperature, compression pressure, feedstock moisture content, and hammer mill screen size in real values are provided in Table 4. To understand the significant effect of linear, quadratic, and interactive effect of process terms in the response surface model with respect to quality attributes (density-1, density-2, DR, and briquette moisture content), ANOVA was performed. Response surface plots were drawn using the regression equations (see Table 4) developed for briquette quality attributes (moisture content, density-1, density-2, and DR). Response surface plots were drawn by changing two process variables, whereas the other two variables were kept constant at the center point of the experimental design.

\section{Briquette Moisture Content}

Moisture content $\left(x_{2}\right)$ of the four feedstocks had a positive correlation and had an extremely significant $(p<0.0001)$ effect on the briquette moisture content. Die temperature $\left(x_{1}\right)$ had an inverse correlation and had a statistically significant effect $(p<0.05$ and $p<0.001)$ on the moisture content of canola 
Fig. 3 Wheat, barley, canola, and oat straw briquettes produced at different experimental conditions

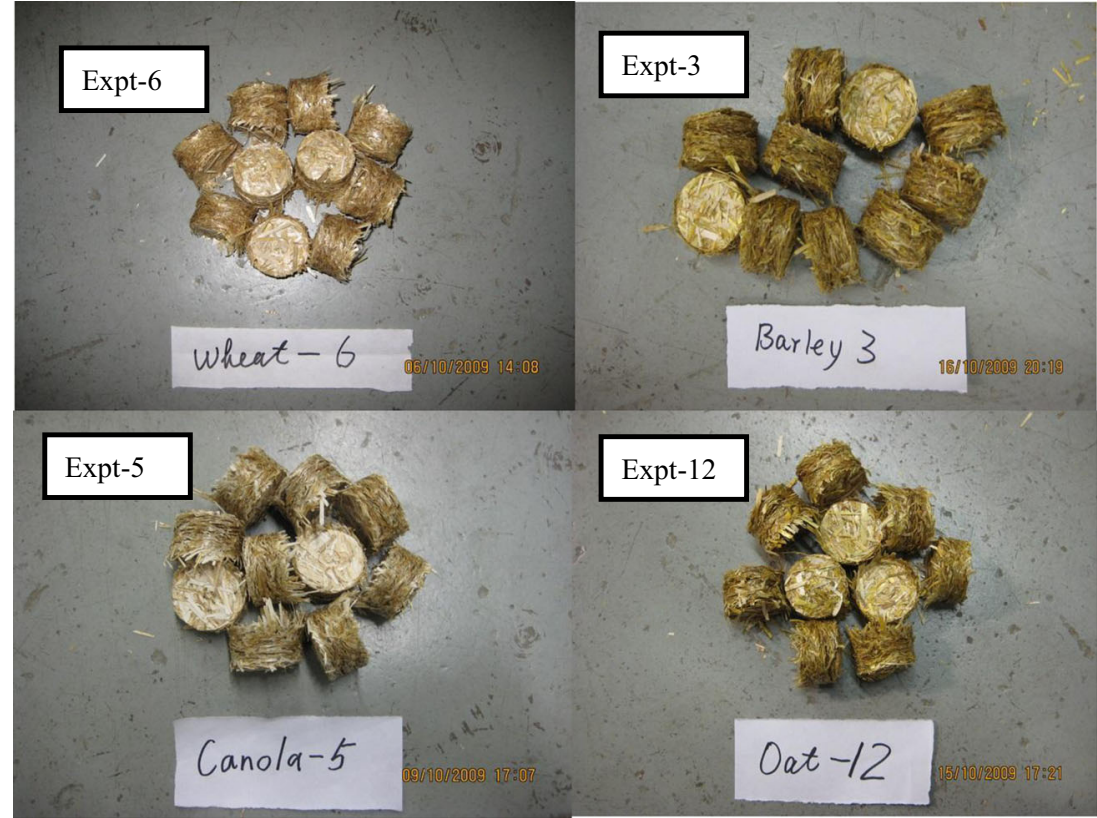

and wheat straw briquettes, but it had no significant effect on barley and oat straw briquettes. Compression pressure $\left(x_{3}\right)$ also played a significant effect on wheat and oat briquettes at $p<0.05$, while hammer mill screen size $\left(x_{4}\right)$ was significant only for the wheat briquettes at $p<0.001$. Higher moisture in the briquette resulted when the feedstock moisture content $\left(x_{2}\right)$ was at about $15 \%$ (w.b.). Mani et al. [16, 35] observed that high initial moisture of about $15 \%$ (w.b.) can have a negative effect on the final briquette and pellet quality in terms of unit density. Feedstock moisture content played a major role on the briquette moisture content. Lowering the feedstock moisture content to $9 \%$ (w.b.), and increasing the die temperature to $130{ }^{\circ} \mathrm{C}$ resulted in a lower briquette moisture content of about 7.34, 7.6, and $8.4 \%$ (w.b.) in canola (Fig. 4), barley, and wheat straw briquettes (figures not shown), respectively. In the case of oat straw briquettes, a lower briquette moisture content of about $7.74 \%$ (w.b.) was observed at a low feedstock moisture content of $9 \%$ (w.b.) and a higher compression pressure of $12.5 \mathrm{MPa}$.

\section{Unit Density: Immediately After Compaction (Density-1), and After 2 Weeks of Storage (Density-2)}

ANOVA indicated that die temperature $\left(x_{1}\right)$ during briquetting had no significant effect on density- 1 and density- 2 of barley, canola, oat, and wheat straw briquettes. The results showed that moisture content $\left(x_{2}\right)$ of the four feedstocks significantly $(p<0.0001)$ affected the initial and final unit densities. Feedstock moisture content $\left(x_{2}\right)$ plays a major role on binding characteristics during the briquetting process. The results also indicated that feedstock moisture content $\left(x_{2}\right)$ is negatively correlated with briquette unit density, which corroborated with the findings of Colley et al. [9] and Mani et al. [16]. The compression pressure $\left(x_{3}\right)$ and screen size $\left(x_{4}\right)$ positively affected briquette unit density (i.e., the higher pressure and bigger screen size resulted in higher unit densities) for all of the feedstocks studied. Compression pressure $\left(x_{3}\right)$ was found to have no significant effect on the initial unit density (density1 ) of wheat and oat straw briquettes, while screen size $\left(x_{4}\right)$ was found to have no significant effect for both density-1 and density-2. These results indicate that the effect of feedstock moisture content $\left(x_{2}\right)$ is more significant than that of compression pressure $\left(x_{3}\right)$ for the formation of briquettes with a high unit density. A maximum density-1 of $>900 \mathrm{~kg} / \mathrm{m}^{3}$ for canola (Fig. 5) and $>700 \mathrm{~kg} / \mathrm{m}^{3}$ for barley, wheat, and oat straw briquettes (figures not shown) was predicted at a feedstock moisture content of $9 \%$ (w.b.). The other process variable that influenced canola, barley, and oat straw briquetting was compression pressure of $12.5 \mathrm{MPa}$, whereas for wheat straw, it was a larger screen size of $31.75 \mathrm{~mm}$. The significance of the process variables on density- 2 was similar to density- 1 , where feedstock moisture content significantly affected $(p>0.01)$ the feedstocks, whereas compression pressure was significant for canola (Fig. 6), barley, and oat (figures not shown) and screen size for wheat straw briquettes. Density-2 values in the range of 650 to $700 \mathrm{~kg} / \mathrm{m}^{3}$ were maintained after 2 weeks of storage, when briquettes were prepared at a low initial feedstock moisture content of $9 \%$ (w.b.) and higher compression pressure of 12.5 MPa for canola, barley, and oat straw briquettes. In the case of wheat straw briquettes, however, a low initial feedstock 
Table 4 Regression equations developed for briquette quality attributes

\begin{tabular}{|c|c|c|}
\hline Briquette quality & Response surface model & $R^{2}$ \\
\hline \multicolumn{3}{|l|}{ Canola } \\
\hline $\mathrm{MC}$ & $\begin{array}{l}-12.83+0.055 \mathrm{x}_{1}+2.06 \mathrm{x}_{2}+0.0073 \mathrm{x}_{3}+0.38 \mathrm{x}_{4}-0.0002 \mathrm{x}_{1}^{2}-0.0528 \mathrm{x}_{2}^{2}-0.02 \mathrm{x}_{3}^{2}- \\
0.0064 \mathrm{x}_{4}^{2}-0.0013 \mathrm{x}_{1} \mathrm{x}_{2}+0.0015 \mathrm{x}_{1} \mathrm{x}_{3}-0.0012 \mathrm{x}_{1} \mathrm{x}_{4}+0.01 \mathrm{x}_{2} \mathrm{x}_{3}+0.0012 \mathrm{x}_{2} \mathrm{x}_{4}+ \\
\quad 0.004 \mathrm{x}_{3} \mathrm{x}_{4}\end{array}$ & 0.98 \\
\hline Density-1 & $\begin{array}{l}-92.8867-10.087 \mathrm{x}_{1}+130.11 \mathrm{x}_{2}+111.49 \mathrm{x}_{3}-2.0 \mathrm{x}_{4}+0.0773 \mathrm{x}_{1}{ }^{2}-1.58 \mathrm{x}_{2}{ }^{2}-2.61 \mathrm{x}_{3}{ }^{2}+ \\
0.41 \mathrm{x}_{4}^{2}-0.46 \mathrm{x}_{1} \mathrm{x}_{2}+0.03 \mathrm{x}_{1} \mathrm{x}_{3}-0.08 \mathrm{x}_{1} \mathrm{x}_{4}-4.5 \mathrm{x}_{2} \mathrm{x}_{3}-0.61 \mathrm{x}_{2} \mathrm{x}_{4}+0.125 \mathrm{x}_{3} \mathrm{x}_{4}\end{array}$ & 0.93 \\
\hline Density-2 & $\begin{array}{l}\text { 64.10-10.90 } \mathrm{x}_{1}+125.28 \mathrm{x}_{2}+104.23 \mathrm{x}_{3}-7.14 \mathrm{x}_{4}+0.08 \mathrm{x}_{1}^{2}-1.56 \mathrm{x}_{2}^{2}-2.10 \mathrm{x}_{3}^{2}+ \\
0.44 \mathrm{x}_{4}^{2}-0.41 \mathrm{x}_{1} \mathrm{x}_{2}-0.005 \mathrm{x}_{1} \mathrm{x}_{3}-0.05 \mathrm{x}_{1} \mathrm{x}_{4}-4.6 \mathrm{x}_{2} \mathrm{x}_{3}-0.63 \mathrm{x}_{2} \mathrm{x}_{4}+0.20 \mathrm{x}_{3} \mathrm{x}_{4}\end{array}$ & 0.93 \\
\hline DR & $\begin{array}{l}297.90-1.96 \mathrm{x}_{1}-6.56 \mathrm{x}_{2}-4.70 \mathrm{x}_{3}-3.63 \mathrm{x}_{4}+0.016 \mathrm{x}_{1}^{2}-0.037 \mathrm{x}_{2}^{2}+0.37 \mathrm{x}_{3}^{2}+0.023 \mathrm{x}_{4}^{2}+ \\
0.0042 \mathrm{x}_{1} \mathrm{x}_{2}-0.01 \mathrm{x}_{1} \mathrm{x}_{3}-0.0063 \mathrm{x}_{1} \mathrm{x}_{4}-0.13 \mathrm{x}_{2} \mathrm{x}_{3}+0.30 \mathrm{x}_{2} \mathrm{x}_{4}-0.0145 \mathrm{x}_{3} \mathrm{x}_{4}\end{array}$ & 0.77 \\
\hline \multicolumn{3}{|c|}{$\mathrm{C}$} \\
\hline MC & $\begin{array}{l}27.87-0.19 \mathrm{x}_{1}-0.09 \mathrm{x}_{2}-0.74 \mathrm{x}_{3}-0.485 \mathrm{x}_{4}+0.00051 \mathrm{x}_{1}^{2}+0.016 \mathrm{x}_{2}^{2}+0.032 \mathrm{x}_{3}^{2}+ \\
0.0026 \mathrm{x}_{4}^{2}+0.0029 \mathrm{x}_{1} \mathrm{x}_{2}+0.0015 \mathrm{x}_{1} \mathrm{x}_{3}+0.0058 \mathrm{x}_{1} \mathrm{x}_{4}-0.03 \mathrm{x}_{2} \mathrm{x}_{3}+0.014 \mathrm{x}_{2} \mathrm{x}_{4}+ \\
\quad 0.0083 \mathrm{x}_{3} \mathrm{x}_{4}\end{array}$ & 0.93 \\
\hline Density-1 & $\begin{array}{c}1107.85-4.86 \mathrm{x}_{1}+42.2 \mathrm{x}_{2}-24.79 \mathrm{x}_{3}-16.30 \mathrm{x}_{4}+0.023 \mathrm{x}_{1}{ }^{2}-2.764 \mathrm{x}_{2}{ }^{2}+1.720 \mathrm{x}_{3}{ }^{2}+ \\
0.46 \mathrm{x}_{4}^{2}-0.14 \mathrm{x}_{1} \mathrm{x}_{2}+0.205 \mathrm{x}_{1} \mathrm{x}_{3}-0.02 \mathrm{x}_{1} \mathrm{x}_{4}-0.933 \mathrm{x}_{2} \mathrm{x}_{3}+0.32 \mathrm{x}_{2} \mathrm{x}_{4}-0.59 \mathrm{x}_{3} \mathrm{x}_{4}\end{array}$ & 0.97 \\
\hline Density-2 & $\begin{array}{l}\text { 794.4-2.51 } \mathrm{x}_{1}+52.65 \mathrm{x}_{2}-26.52 \mathrm{x}_{3}-8.10 \mathrm{x}_{4}+0.015 \mathrm{x}_{1}^{2}-2.77 \mathrm{x}_{2}^{2}+1.75 \mathrm{x}_{3}^{2}+0.37 \mathrm{x}_{4}^{2}- \\
0.14 \mathrm{x}_{1} \mathrm{x}_{2}+0.18 \mathrm{x}_{1} \mathrm{x}_{3}-0.026 \mathrm{x}_{1} \mathrm{x}_{4}-1.1 \mathrm{x}_{2} \mathrm{x}_{3}-0.07 \mathrm{x}_{2} \mathrm{x}_{4}-0.39 \mathrm{x}_{3} \mathrm{x}_{4}\end{array}$ & 0.97 \\
\hline DR & $\begin{array}{l}-43.52+0.42 \mathrm{x}_{1}+18.05 \mathrm{x}_{2}-5.57 \mathrm{x}_{3}+2.75 \mathrm{x}_{4}-0.0014 \mathrm{x}_{1}^{2}-1.14 \mathrm{x}_{2}^{2}+0.15 \mathrm{x}_{3}^{2}- \\
0.08 \mathrm{x}_{4}^{2}+0.01 \mathrm{x}_{1} \mathrm{x}_{2}+0.045 \mathrm{x}_{1} \mathrm{x}_{3}-0.02 \mathrm{x}_{1} \mathrm{x}_{4}-0.43 \mathrm{x}_{2} \mathrm{x}_{3}+0.33 \mathrm{x}_{2} \mathrm{x}_{4}+0.09 \mathrm{x}_{3} \mathrm{x}_{4}\end{array}$ & 0.90 \\
\hline \multicolumn{3}{|c|}{$\mathrm{C}_{4}$} \\
\hline $\mathrm{MC}$ & $\begin{array}{l}2.39-0.00059 \mathrm{x}_{1}+0.97 \mathrm{x}_{2}+1.18 \mathrm{x}_{3}-0.54 \mathrm{x}_{4}+0.0004 \mathrm{x}_{1}^{2}-0.002 \mathrm{x}_{2}^{2}-0.02 \mathrm{x}_{3}{ }^{2}+ \\
0.005 \mathrm{x}_{4}{ }^{2}-0.0045 \mathrm{x}_{1} \mathrm{x}_{2}-0.0035 \mathrm{x}_{1} \mathrm{x}_{3}-0.0001 \mathrm{x}_{1} \mathrm{x}_{4}-0.037 \mathrm{x}_{2} \mathrm{x}_{3}+0.023 \mathrm{x}_{2} \mathrm{x}_{4}+ \\
0.000064 \mathrm{x}_{3} \mathrm{x}_{4}\end{array}$ & 0.96 \\
\hline Density-1 & $\begin{array}{l}-2622.78+23.39 \mathrm{x}_{1}+192.37 \mathrm{x}_{2}+33.09 \mathrm{x}_{3}+57.28 \mathrm{x}_{4}-0.07 \mathrm{x}_{1}{ }^{2}-5.76 \mathrm{x}_{2}{ }^{2}-2.15 \mathrm{x}_{3}{ }^{2}- \\
0.44 \mathrm{x}_{4}{ }^{2}-0.53 \mathrm{x}_{1} \mathrm{x}_{2}-0.01 \mathrm{x}_{1} \mathrm{x}_{3}-0.02 \mathrm{x}_{1} \mathrm{x}_{4}+1.70 \mathrm{x}_{2} \mathrm{x}_{3}-2.13 \mathrm{x}_{2} \mathrm{x}_{4}-0.07 \mathrm{x}_{3} \mathrm{x}_{4}\end{array}$ & 0.94 \\
\hline Density-2 & $\begin{array}{l}-2270.37+21.43 \mathrm{x}_{1}-181.18 \mathrm{x}_{2}+0.86 \mathrm{x}_{3}+53.77 \mathrm{x}_{4}-0.07 \mathrm{x}_{1}^{2}-6.83 \mathrm{x}_{2}^{2}-1.18 \mathrm{x}_{3}{ }^{2}- \\
0.70 \mathrm{x}_{4}{ }^{2}-0.47 \mathrm{x}_{1} \mathrm{x}_{2}+0.05 \mathrm{x}_{1} \mathrm{x}_{3}-0.01 \mathrm{x}_{1} \mathrm{x}_{4}+1.97 \mathrm{x}_{2} \mathrm{x}_{3}-0.96 \mathrm{x}_{2} \mathrm{x}_{4}+0.07 \mathrm{x}_{3} \mathrm{x}_{4}\end{array}$ & 0.96 \\
\hline DR & $\begin{array}{l}158.50+1.73 \mathrm{x}_{1}+7.39 \mathrm{x}_{2}-16.45 \mathrm{x}_{3}-11.06 \mathrm{x}_{4}-0.016 \mathrm{x}_{1}^{2}-1.12 \mathrm{x}_{2}^{2}+0.13 \mathrm{x}_{3}^{2}-0.01 \mathrm{x}_{4}{ }^{2}+ \\
0.04 \mathrm{x}_{1} \mathrm{x}_{2}+0.03 \mathrm{x}_{1} \mathrm{x}_{3}+0.058 \mathrm{x}_{1} \mathrm{x}_{4}+0.47 \mathrm{x}_{2} \mathrm{x}_{3}+0.30 \mathrm{x}_{2} \mathrm{x}_{4}+0.21 \mathrm{x}_{3} \mathrm{x}_{4}\end{array}$ & 0.81 \\
\hline Oat & $\mathrm{C}$ & \\
\hline $\mathrm{MC}$ & $\begin{array}{l}16.46-0.09 \mathrm{x}_{1}+0.003 \mathrm{x}_{2}-0.36 \mathrm{x}_{3}-0.25 \mathrm{x}_{4}+0.00027 \mathrm{x}_{1}^{2}-0.0004 \mathrm{x}_{2}^{2}-0.17 \mathrm{x}_{3}^{2}+ \\
0.0041 \mathrm{x}_{4}^{2}+0.00083 \mathrm{x}_{1} \mathrm{x}_{2}-0.000001 \mathrm{x}_{1} \mathrm{x}_{3}+0.0006 \mathrm{x}_{1} \mathrm{x}_{4}+0.067 \mathrm{x}_{2} \mathrm{x}_{3}- \\
0.0029 \mathrm{x}_{2} \mathrm{x}_{4}+0.00013 \mathrm{x}_{3} \mathrm{x}_{4}\end{array}$ & 0.96 \\
\hline Density-1 & $\begin{array}{l}-1621.94+26.51 \mathrm{x}_{1}+114.86 \mathrm{x}_{2}+46.92 \mathrm{x}_{3}+7.69 \mathrm{x}_{4}-0.08 \mathrm{x}_{1}{ }^{2}-3.02 \mathrm{x}_{2}{ }^{2}-1.43 \mathrm{x}_{3}{ }^{2}- \\
0.55 \mathrm{x}_{4}{ }^{2}-0.555 \mathrm{x}_{1} \mathrm{x}_{2}-0.24 \mathrm{x}_{1} \mathrm{x}_{3}+0.01 \mathrm{x}_{1} \mathrm{x}_{4}-2.73 \mathrm{x}_{2} \mathrm{x}_{3}+0.11 \mathrm{x}_{2} \mathrm{x}_{4}+1.66 \mathrm{x}_{3} \mathrm{x}_{4}\end{array}$ & 0.98 \\
\hline Density-2 & $\begin{array}{c}-2393+25.64 \mathrm{x}_{1}+112.72 \mathrm{x}_{2}+121.52 \mathrm{x}_{3}+37.99 \mathrm{x}_{4}-0.06 \mathrm{x}_{1}^{2}-2.58 \mathrm{x}_{2}^{2}-1.93 \mathrm{x}_{3}^{2}- \\
0.74 \mathrm{x}_{4}^{2}-0.55 \mathrm{x}_{1} \mathrm{x}_{2}-0.50 \mathrm{x}_{1} \mathrm{x}_{3}-0.01 \mathrm{x}_{1} \mathrm{x}_{4}-2.87 \mathrm{x}_{2} \mathrm{x}_{3}-0.15 \mathrm{x}_{2} \mathrm{x}_{4}+0.34 \mathrm{x}_{3} \mathrm{x}_{4}\end{array}$ & 0.96 \\
\hline DR & $\begin{array}{l}264.46+3.71 \mathrm{x}_{1}+25.45 \mathrm{x}_{2}+7.27 \mathrm{x}_{3}-2.29 \mathrm{x}_{4}-0.01 \mathrm{x}_{1}^{2}-1.03 \mathrm{x}_{2}^{2}-0.33 \mathrm{x}_{3}^{2}+0.016 \mathrm{x}_{4}{ }^{2}- \\
0.042 \mathrm{x}_{1} \mathrm{x}_{2}-0.005 \mathrm{x}_{1} \mathrm{x}_{3}-0.028 \mathrm{x}_{1} \mathrm{x}_{4}-0.667 \mathrm{x}_{2} \mathrm{x}_{3}+0.263 \mathrm{x}_{2} \mathrm{x}_{4}+0.239 \mathrm{x}_{3} \mathrm{x}_{4}\end{array}$ & 0.98 \\
\hline
\end{tabular}

Density-1: average density $\left(\mathrm{kg} / \mathrm{m}^{3}\right)$ of briquettes immediately after compaction; $M C$ average briquette moisture content (\% w.b.) after 2 weeks of storage, density-2: average density $\left(\mathrm{kg} / \mathrm{m}^{3}\right)$ of briquettes after 2 weeks of storage, and DR: durability rating of briquettes after 2 weeks of storage; $x_{1}$ die temperature $\left({ }^{\circ} \mathrm{C}\right), x_{2}$ feedstock moisture content $\left(\%\right.$, w.b), $x_{3}$ compression pressure $(\mathrm{MPa})$, and $x_{4}$ screen size $(\mathrm{mm})$ of the hammer mill used to grind the biomass

moisture content of $9 \%$ (w.b.) and larger screen size of $31.75 \mathrm{~mm}$ resulted in final bulk density values of 600 to $650 \mathrm{~kg} / \mathrm{m}^{3}$ after 2 weeks of storage.

\section{Durability Rating}

ANOVA indicated that die temperature $\left(x_{1}\right)$ had a positive correlation with briquette durability rating (DR), while feedstock moisture content $\left(x_{2}\right)$ had a negative correlation. The high die temperature $\left(x_{1}\right)$ used in producing briquettes resulted in better DR, which made the briquettes withstand the shear, impact, tumbling, and rotational forces during DR testing. The high die temperature assisted in the local melting of the biomass binding constituents (such as lignin), which subsequently leads to the mechanical interlocking of the biomass particles [35]. These results confirmed the high values of DR in Table 3 , where a high die temperature $\left(130{ }^{\circ} \mathrm{C}\right)$ with appropriate combinations of other material and process variables resulted in high-durability briquettes. Die temperature $\left(x_{1}\right)$ and feedstock moisture content $\left(x_{2}\right)$ significantly affected $(p<0.001)$ the DR values of oat, barley, canola, and wheat straw briquettes. However, compression pressure $\left(x_{3}\right)$ had no 
Fig. 4 Moisture content of canola straw briquette with respect to feedstock moisture content and die temperature

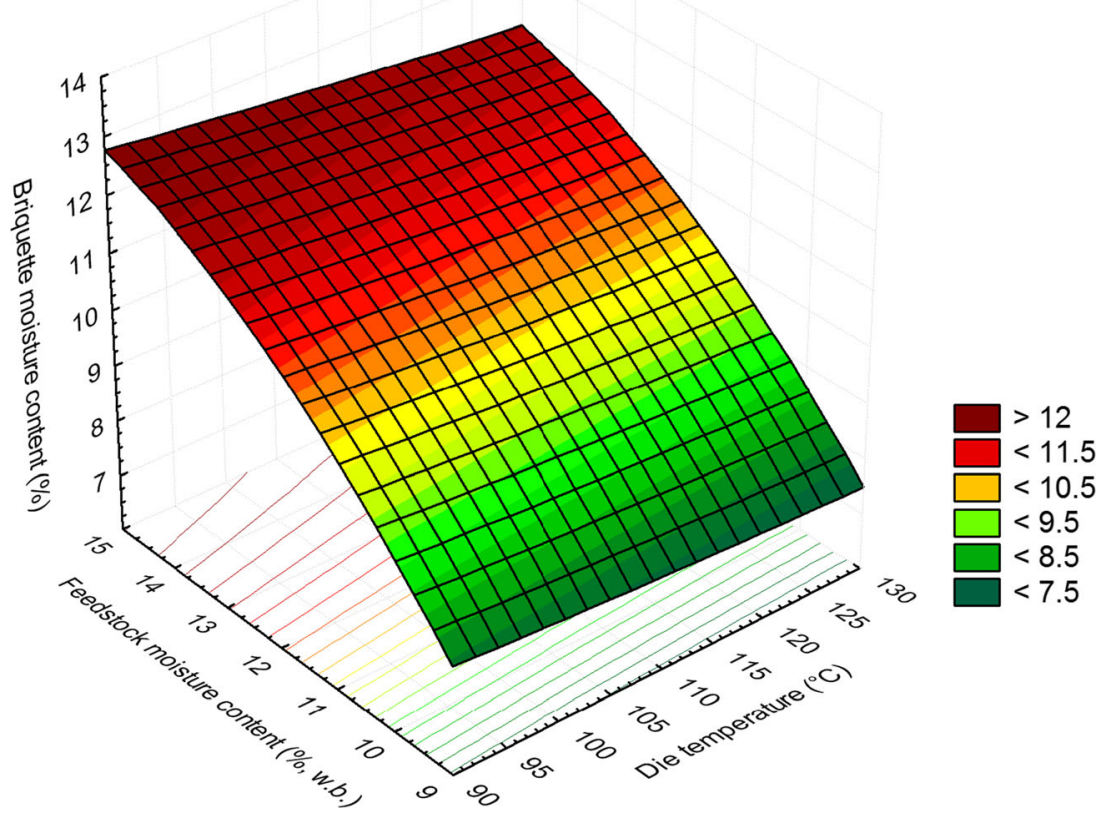

significant effect on the DR values of barley, canola, and wheat straw briquettes, but had significant effect $(p<0.001)$ for oat straw briquettes. ANOVA indicated that hammer mill screen size $\left(x_{4}\right)$ had a positive correlation with briquette DR values. Through optimal combinations with other variables, large screen size straws can produce briquettes with high DR values (see Table 3). Canola (Fig. 7), wheat, and oat straw (figures not shown) briquettes, higher DR values of $>95 \%$ were predicted at high die temperature of $130{ }^{\circ} \mathrm{C}$ and a lower feedstock moisture content of $9 \%$ (w.b.). In the case of canola straw briquettes, both high and low feedstock moisture contents yielded highly durable briquettes at high die temperature. Lowering the die temperature and increasing the feedstock moisture content reduced the DR values. For barley straw briquettes, feedstock moisture content was the influencing process variable, where at $9 \%$ (w.b.), it resulted in maximizing
Fig. 5 Density-1 (unit density immediately after compaction) of canola straw briquette with respect to compression pressure and feedstock moisture content

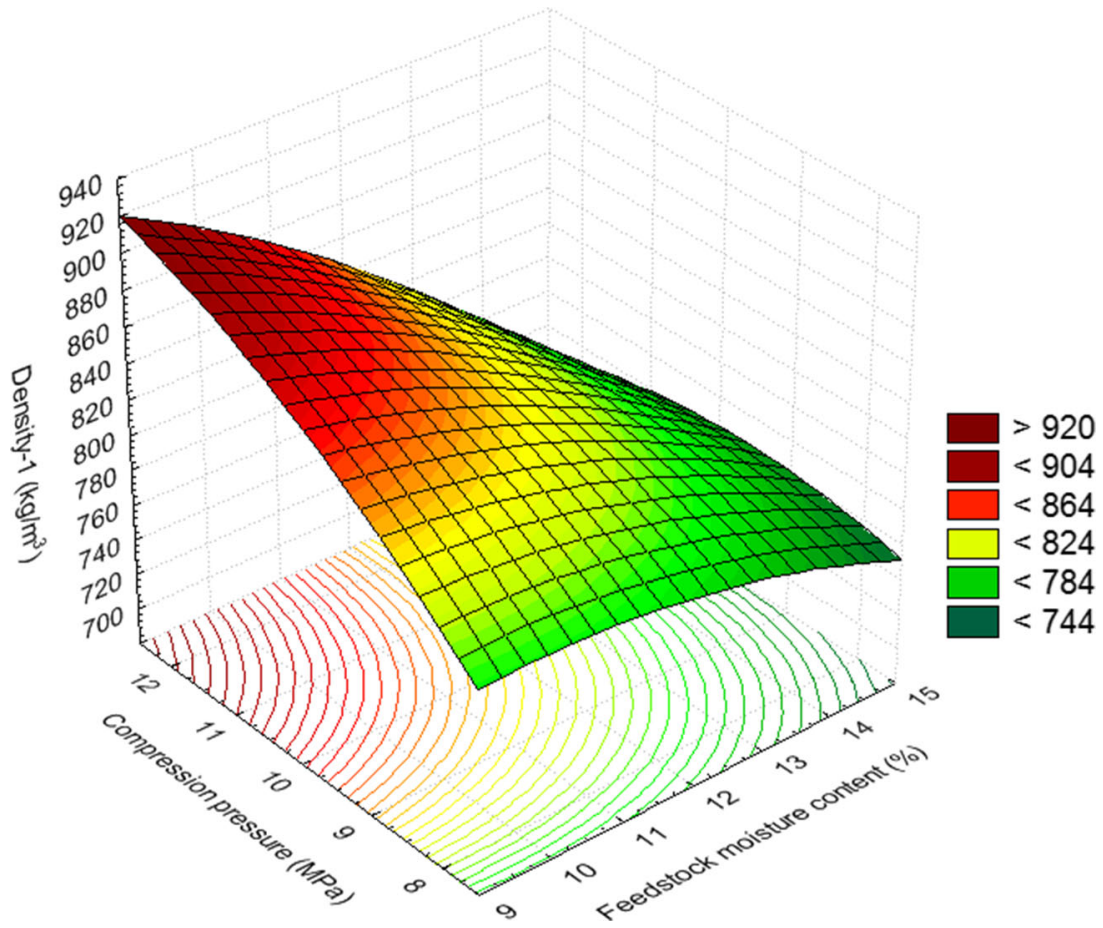


Fig. 6 Density-2 (unit density after 2 weeks of storage) of canola straw briquette with respect to compression pressure and feedstock moisture content

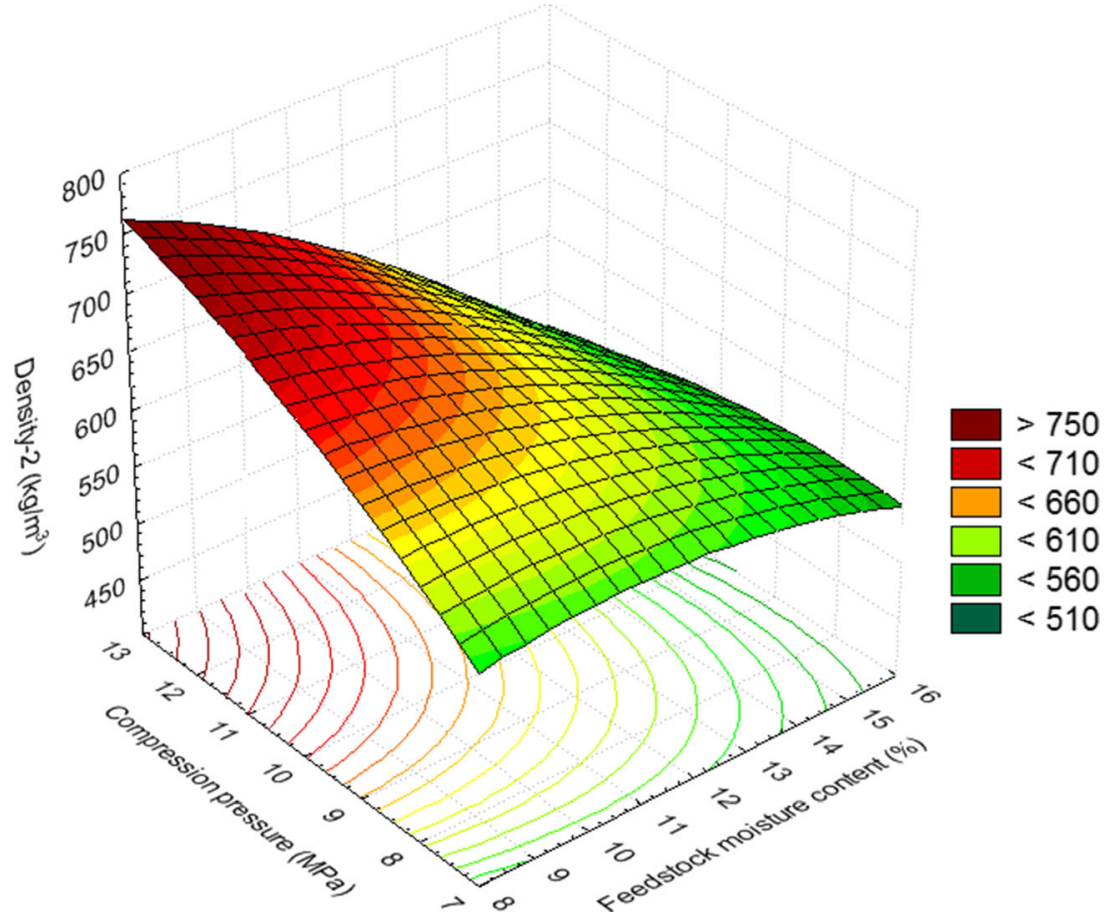

DR values to $>90 \%$ in the temperature range of 90 to $130{ }^{\circ} \mathrm{C}$ using medium screen size of about $24 \mathrm{~mm}$. The response surface plot analysis of the experimental data indicated trends of the process variables which can maximize density-1, density-2, and DR and minimize the briquette moisture content but could not precisely pinpoint the optimized process conditions.
The response surface models developed were further optimized using genetic algorithm to identify the process conditions to maximize density-1, density-2, and DR and minimize the briquette moisture content (Table 5). Higher die temperatures of $>122^{\circ} \mathrm{C}$ maximized density-1, density-2, and DR and minimized the briquette moisture content, except for canola where lower die temperature of about $93^{\circ} \mathrm{C}$ was found to be
Fig. 7 Durability rating of canola straw briquette with respect to die temperature and feedstock moisture content

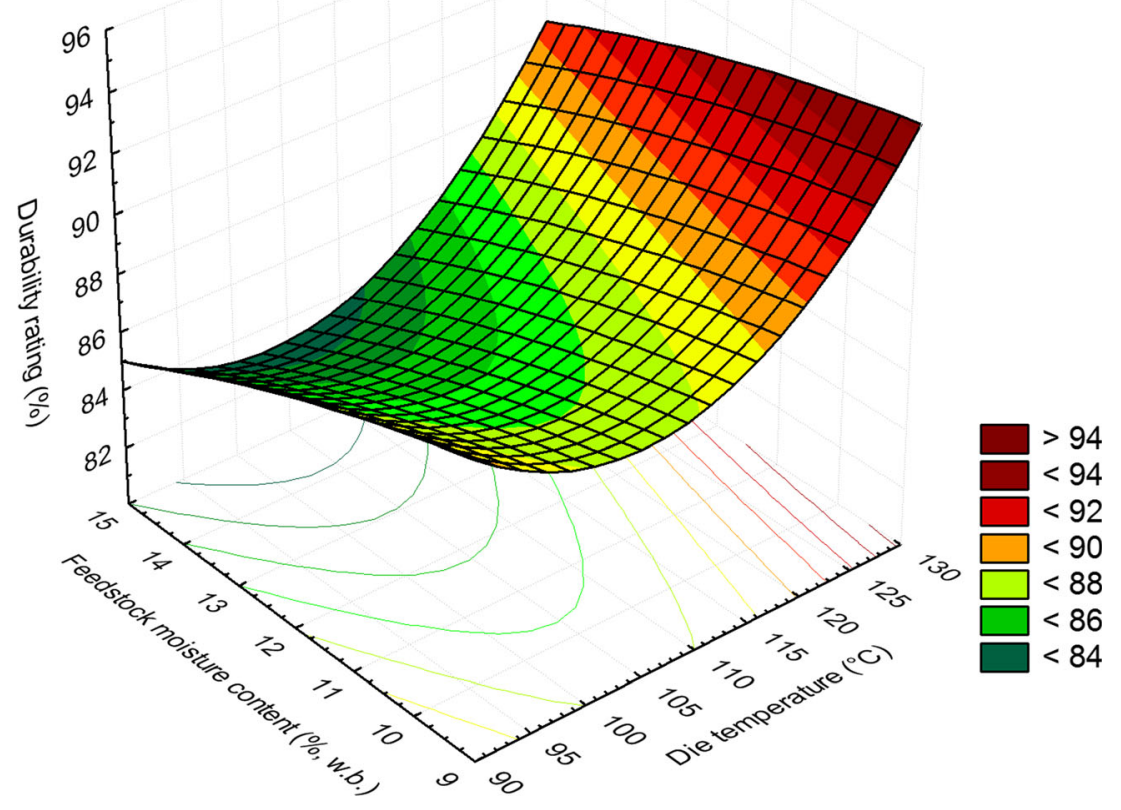


Table 5 Optimum process conditions to produce high-quality agricultural straw briquettes

\begin{tabular}{|c|c|c|c|c|c|c|}
\hline & Die temperature $\left({ }^{\circ} \mathrm{C}, x_{1}\right)$ & $\begin{array}{l}\text { Feedstock moisture } \\
\text { content }\left(\%, \text { w.b., } x_{2}\right)\end{array}$ & $\begin{array}{l}\text { Compression } \\
\text { pressure }\left(\mathrm{MPa}, x_{3}\right)\end{array}$ & $\begin{array}{l}\text { Hammer mill screen } \\
\text { size }\left(\mathrm{mm}, x_{4}\right)\end{array}$ & Predicted values & Objective \\
\hline \multicolumn{7}{|l|}{ Canola } \\
\hline $\mathrm{MC}$ & 129.88 & 9.0 & 7.54 & 31.52 & 6.77 & Minimize \\
\hline Density-1 & 129.97 & 9.88 & 11.52 & 31.39 & 976.61 & Maximize \\
\hline Density-2 & 92.80 & 9.03 & 12.46 & 31.63 & 800.05 & Maximum \\
\hline DR & 128.87 & 14.52 & 7.86 & 31.61 & 99.7 & Maximum \\
\hline \multicolumn{7}{|l|}{ Barley } \\
\hline $\mathrm{MC}$ & 127.84 & 9.00 & 8.77 & 31.69 & 7.19 & Minimum \\
\hline Density-1 & 129.91 & 9.16 & 12.48 & 31.68 & 755.52 & Maximum \\
\hline Density-2 & 124.68 & 9.10 & 12.45 & 31.01 & 740.35 & Maximum \\
\hline DR & 126.21 & 9.31 & 12.48 & 23.51 & 95.62 & Maximum \\
\hline \multicolumn{7}{|l|}{ Wheat } \\
\hline $\mathrm{MC}$ & 92.80 & 9.00 & 7.50 & 31.62 & 7.42 & Minimum \\
\hline Density-1 & 125.47 & 9.04 & 10.64 & 31.60 & 795.38 & Maximum \\
\hline Density-2 & 122.13 & 9.06 & 11.05 & 31.61 & 704.81 & Maximum \\
\hline DR & 127.70 & 11.81 & 12.35 & 31.56 & 99.2 & Maximum \\
\hline \multicolumn{7}{|l|}{ Oat } \\
\hline $\mathrm{MC}$ & 128.94 & 9.00 & 12.42 & 24.30 & 7.37 & Minimum \\
\hline Density-1 & 118.96 & 9.19 & 12.16 & 27.75 & 716.65 & Maximum \\
\hline Density-2 & 119.79 & 9.00 & 12.07 & 25.35 & 707.59 & Maximum \\
\hline DR & 123.99 & 9.58 & 8.27 & 19.28 & 99.23 & Maximum \\
\hline
\end{tabular}

Density-1 average density $\left(\mathrm{kg} / \mathrm{m}^{3}\right)$ of briquettes immediately after compaction, $M C$ average briquette moisture content (\% w.b.) after 2 weeks of storage, density-2 average density $\left(\mathrm{kg} / \mathrm{m}^{3}\right)$ of briquettes after 2 weeks of storage, and $D R$ durability rating of briquettes after 2 weeks of storage

sufficient. Low feedstock moisture content of about $9 \%$ (w.b.) maximized density-1, density-2, and DR values and minimized the briquette moisture content for all the feedstocks, except for wheat and canola where medium (11.81\%, w.b.) and high (14.52\%, w.b.) feedstock moisture content were necessary. Medium to high compression pressures (1012.5 $\mathrm{MPa}$ ) maximized the unit densities of all feedstocks. Large hammer mill screen sizes of $>30 \mathrm{~mm}$ maximized density-1, density-2, and DR and minimized the briquette moisture content for wheat and canola, for barley and oat medium hammer mill screen size particle size $(23.51 \mathrm{~mm})$ and lower $(19.28 \mathrm{~mm})$ maximized the DR values.

\section{Discussion}

Grover and Mishra [8] reported that low feedstock moisture content ( 8 to $10 \%$, w.b.) is optimal for manufacturing of biomass briquette free of cracks. The right amount of moisture in the biomass acts as a facilitator of natural binding agents and as a lubricant $[3,6]$. Many studies have indicated that feedstock moisture content below $8 \%$ (w.b.) or above $12 \%$ (w.b.) would lead to lower-quality pellets or briquettes in terms of density and durability [11, 16, 36-39]. In general, an increase in feedstock moisture content to $>15 \%$ could result in a decrease in pellet or briquette densities [10, 35, 40-43]. Tumuluru et al. [13], in their recent studies, indicated that pelletization at a feedstock moisture content of $38 \%$ (w.b.) decreased the density by about $50 \%$ compared to pellets made at a low feedstock moisture content of $10 \%$ (w.b.). In general, a high feedstock moisture content of $15 \%$ (w.b.) results in expansion of the briquette volume causing a decrease in the density [16]. However, the percentage decrease in density depends on the type of biomass pelleted or briquetted. Therefore, a feedstock moisture content of about $10 \%$ (w.b.) is considered optimal to obtain highly dense and durable briquettes, which has been corroborated by the present findings. High briquette moisture content may not be desirable in thermochemical conversion applications because it reduces the thermal efficiency due to heat being used to drive off the water. The storage stability of high moisture briquettes is reduced because it hastens the product's biological degradation and increases the dry matter losses. Lowering the briquette moisture to $<5 \%$ (w.b.) can break up the briquettes (fragile), creating more fines during storage and transportation. Therefore, an optimal briquette moisture content of about $8-10 \%$ (w.b.) is desirable for safe storage and reduced 
transportation losses. The present results indicated that canola straw briquetted better at low feedstock moisture content and high die temperature to produce briquettes with high initial and final densities when compared to wheat, barley, and oat straws. The reason for this may be due to the higher protein content in the canola straw, which may have resulted in the formation of protein-fat complexes in the presence of heat and compression pressure, resulting in better binding.

In almost all cases, there was a decrease in the unit density of the briquettes after 2 weeks of storage. The reason for this was due to the dimensional instability, which was more significant in the axial direction (height) than in the lateral direction (diameter), which in some cases tend to be very marginal depending on the combination of the material and operating variables. A similar expansion trend was also reported by Mani et al. [19] on the compaction of corn stover and by Al-Widyan et al. [44] on the stability of olive cake briquettes. Dimensional stability is mainly dependent on feedstock moisture content and compression pressure. The present study indicated that a change in density or decrease in dimensional stability is more significant at a high feedstock moisture content of $15 \%$ (w.b.) and lower compression pressure of 7.5 $\mathrm{MPa}$. The high feedstock moisture content and lowcompression pressure may not have provided the enabling condition for mechanical interlocking and the binding effect of the particles. The present results suggest that briquettes made with canola straw have the lowest change in density, indicating a higher dimensional stability during storage. The positive correlation of the screen size indicates that large hammer mill screen size may result in briquettes with high density as much as when an appropriate combination with feedstock moisture content, die temperature, and compression pressure is made.

At high die temperature $\left(130^{\circ} \mathrm{C}\right)$ and low feedstock moisture (9 to $12 \%$, w.b.), briquettes with a high DR were produced. Present results show that large hammer mill screen sizes resulted in higher durability due to better interlocking of particles during the briquetting process. Also, high die temperatures associated with the briquetting process may result in the melting points of some constituents (such as lignin) being approached, alongside local melting of the materials, resulting in the binding of the particles. The present study indicates that a combination of low feedstock moisture (9\%,w.b.) and high compression pressure and die temperature and large hammer mill screen size resulted in higher durability rating values. However, in some cases, the durability rating decreased at a high compression pressure $(12.5 \mathrm{MPa})$ due to high feedstock moisture content (15\%, w.b.), which then resulted in surface cracks. Mani et al. [19] reported similar observations where high feedstock moisture content $(15 \%$, w.b.) was predominantly responsible for low durability rating in briquettes. In this study, the lowest DR values are produced at $15 \%$ (w.b.) moisture, except for canola, where low and high feedstock moisture content favored high durability values at high die temperatures of $>120^{\circ} \mathrm{C}$.

This investigation indicates that low to high compression pressures of about 7.5 to $12.5 \mathrm{MPa}$ can produce better quality briquettes only if an optimal combination with other independent variables are selected. This implies that energy costs incurred by high-compression pressure application during the densification process can be reduced if biomass with optimal feedstock moisture and particle size and die temperatures are used. According to Mani et al. [16], compression pressure has the highest effect on the total energy consumption. The screen size of the grinder plays a role in the briquetting process. However, its effect is not as significant as feedstock moisture content, compression pressure, and die temperature. This study indicated that using large hammer mill screen size in appropriate combination with other material and process variables could help to produce good quality briquettes, which might reduce the production cost. Mani et al. [45], Kaliyan and Morey [7], and Tumuluru et al. [20] reported that the energy consumption for grinding increases exponentially as the screen size becomes smaller. Because a briquette is used for direct combustion, a large screen size (25 to $32 \mathrm{~mm}$ ) can be used for briquette formation, while avoiding the high cost of grinding. In the present study, the optimized process conditions identified for briquetting of different feedstock are limited for the experimental design followed. As mentioned earlier, the response surface methodology is a very popular technique that has been used extensively in different chemical processes to understand process variable effect and their interaction effect. With that being said, the optimized process conditions identified in this paper for the response surface models can be further used for scale-up of the briquetting process for the feedstocks studied using evolutionary operation (EVOP) method as proposed by Box and Hunter [46].

\section{Conclusions}

Canola straw produced briquette with a higher initial unit density (density-1) and durability rating (DR) compared to the other three biomass feedstocks. Good quality briquettes, in terms of unit density and durability, can be produced with low to medium feedstock moisture contents of 9 to $12 \%$ (w.b.) and high die temperature $\left(130{ }^{\circ} \mathrm{C}\right)$ and high compression pressure (12.5 MPa). ANOVA indicated that die temperature was positively correlated with DR and did not significantly affect the unit density, while compression pressure was positively correlated with the briquette unit density. Regressions equations developed for barley, wheat, oat, and wheat straw briquette properties (moisture content, unit density immediately after compaction (density-1), unit density after 2 weeks of storage (density-2), and DR) have adequately described the process 
based on the coefficient of determination values. Analysis of these equations using RSM and GA indicated that a lower feedstock moisture content of about 7.5 to $9 \%$ (w.b.), higher die temperature of about 120 to $130^{\circ} \mathrm{C}$, a medium to larger hammer mill screen size of 25 to $31.75 \mathrm{~mm}$, and low to high compression pressure of 7.5 to $12.5 \mathrm{MPa}$ minimizes the briquette moisture content to $<7.5 \%$ (w.b.) and maximizes the density- 1 and density- 2 to $>700 \mathrm{~kg} / \mathrm{m}^{3}$. A maximum DR of $>90 \%$ is achievable at high die temperature of $130{ }^{\circ} \mathrm{C}$, a low to medium feedstock moisture content of 9 to $11 \%$ (w.b.), low to high compression pressure of 7.5-12.5 $\mathrm{MPa}$, and a large hammer mill screen size of about $31.75 \mathrm{~mm}$, except for canola where a low compression pressure of 7.5-8.5 MPa and for oat, small screen size of about $19 \mathrm{~mm}$ are desirable for maximizing the DR values.

Acknowledgments This research was supported financially, in part, by the Cellulosic Biofuel Network of Agriculture and Agri-Food Canada and Department of Energy, Office of Energy Efficiency and Renewable Energy under DOE Idaho Operations Office Contract DE-AC0705ID14517. The authors would like to acknowledge Louis Roth and Bill Crerar of University of Saskatchewan, and David L. Combs of Idaho National Laboratory's R\&D Publications Support Team for the graphics assistance.

Conflict of Interest \& U.S. Department of Energy Disclaimer No competing financial interests exist. This information was prepared as an account of work sponsored by an agency of the US government. Neither the US government nor any agency thereof, nor any of their employees, makes any warranty, express or implied, or assumes any legal liability or responsibility for the accuracy, completeness, or usefulness of any information, apparatus, product, or process disclosed, or represents that its use would not infringe privately owned rights. References herein to any specific commercial product, process, or service by trade name, trademark, manufacturer, or otherwise, do not necessarily constitute or imply its endorsement, recommendation, or favoring by the US government or any agency thereof. The views and opinions of the authors expressed herein do not necessarily state or reflect those of the US government or any agency thereof.

Open Access This article is distributed under the terms of the Creative Commons Attribution License which permits any use, distribution, and reproduction in any medium, provided the original author(s) and the source are credited.

\section{References}

1. Kim S, Dale BE (2004) Global potential bioethanol production from waste crops and crop residues. Biomass Bioenergy 26:361-375

2. Sokhansanj S, Mani S, Stumborg M, Samson R, Fenton J (2006) Production and distribution of cereal straw on the Canadian prairies. Can Biosyst Eng 48:3.39-3.46

3. Tumuluru JS, Wright CT, Hess JR, Kenney KL (2011) A review of biomass densification systems to develop uniform feedstock commodities for bioenergy applications. Biofuels Bioprod Biorefin 5(6): 683-707

4. MacMahon MJ (1984) Additives for physical quality of animal feed. In: Beaven DA (ed) Manufacturing of animal feed. Turret-Wheatland Ltd, Herts, pp 69-70
5. Shaw MD (2008) Feedstock and process variables influencing biomass densification. Ph.D dissertation submitted to Department of Agricultural and Bioresource Engineering, University of Saskatchewan, Saskatoon, Saskatchewan, Canada

6. Kaliyan N, Morey RV (2006a) Factors affecting strength and durability of densified products. American Society of Agricultural and Biological Engineers Annual International Meeting, Portland, Oregon, July 9-12, 2006, Paper Number 066077, St. Joseph, Michigan, USA

7. Kaliyan N, Morey RV (2006b) Densification characteristics of corn stover and switchgrass. American Society of Agricultural and Biological Engineers Annual International Meeting, Portland, Oregon, July 9-12, 2006, Paper Number 066174, St. Joseph, Michigan, USA

8. Grover PD, Mishra SK (1996) Biomass briquetting: Technology and practices. In: Regional Wood Energy Development Program in Asia, Tech. Report GCP/RAS/154/NET. Food and Agricultural Organization of the United Nations, Bangkok, Thailand

9. Colley Z, Fasina OO, Bransby D, Lee YY (2006) Moisture effect on the physical characteristics of switchgrass pellets. Am Soc Agric Biol Eng 49(6):1845-1851

10. Adapa PK, Schoenau GJ, Tabil LG, Sokhansanj S (2005) Cubing characteristics of fractionated sun-cured and dehydrated alfalfa crops. Appl Eng Agric 21(4):671-680

11. Adapa PK, Tabil LG, Schoenau GJ (2009) Compression characteristics of selected ground agricultural biomass. Agric Eng Int CIGR E J 11:1347

12. Adapa PK, Tabil LG, Schoenau GJ (2009) Compaction characteristics of barley, canola, oat, and wheat straw. Biosyst Eng 104:335-344

13. Tumuluru JS (2014) Effect of process variables on density and durability of pellets made from high moisture corn stover. Biosyst Eng 119:45-57

14. Briggs JL, Maier DE, Watkins BA, Behnke KC (1999) Effects of ingredients and processing parameters on pellet quality. Poult Sci 78: 1464-1471

15. van Dam JEG, van den Oever MJA, Teunissen W, Keijsers ERP, Peralta AG (2004) Process for production of high density/high performance binderless boards from whole coconut husk —Part 1: lignin as intrinsic thermosetting binder resin. Ind Crops Prod 19(3):207-216

16. Mani S, Tabil LG, Sokhansanj S (2006) Specific energy requirement for compacting corn stover. Bioresour Technol 97(12):1420-1426

17. Ndiema CKW, Manga PN, Ruttoh CR (2002) Influence of die pressure on relaxation characteristics of briquetted biomass. Energy Convers Manag 43:2157-2161

18. Li Y, Liu H (2000) High pressure densification of wood residues to form an upgraded fuel. Biomass Bioenergy 19:177-186

19. Mani S, Tabil LG, Sokhansanj S (2004a) Compaction of corn stover. ASAE Paper No 041160, presentation at the 2004 ASAE/CSAE Annual International Meeting

20. Tumuluru JS, Tabil LG, Song Y, Iroba KL, Meda V (2014) Grinding energy and physical properties of chopped and hammer-milled barley, wheat, oat and canola straws. Biomass Bioenergy 60:58-67

21. ASABE Standards S358.2 (2008) Moisture measurement - forages. American Society of Agricultural and Biological Engineers, St. Joseph

22. ASABE Standards S269.4 (2007) Cubes, pellets, and crumbles definitions and methods for determining density, durability, and moisture content. American Society of Agricultural and Biological Engineers, St. Joseph

23. Sokhansanj S, Mani S, Bi X, Zaini P, Tabil LG (2005) Binderless pelletization of biomass. Presented at the ASAE Annual International Meeting, Tampa, FL, ASAE Paper No. 056061. ASAE, 2950 Niles Road, St. Joseph, MI 49085-9659 USA, July 17-20, 2005

24. Khuri AZ, Cornell JA (1987) Response surface designs and analysis. Marcel Dekker, New York, p 149 
25. Frazier PH, Crawshaw A, Daniels NWR, Eggitt PWR (1983) Optimization of process variables in extrusion cooking of soya. In: Jowitt R (ed) Extrusion cooking technology. Elsevier Applied Science Publishers, London, England, pp 1-26

26. Myers RH (1971) Response surface methodology. Allyn and Bacon, Inc., Boston

27. StatSoft, Inc. (2010) STATISTICA (data analysis software system), version 9.1 (www.statsoft.com)

28. Holland JH (1992) Genetic algorithms. Sci Am 7:66-72

29. Goldberg DE (2001) Genetic algorithms in search, optimization and machine learning. Pearson Education, Singapore

30. Deb K (1995) Optimization for engineering design-algorithms and examples. Prentice Hall of India Pvt. Ltd, New Delhi, India

31. Davis L (ed) (1991) Handbook of genetic algorithms. Van Nostrand, Reinhold, New York

32. Shankar TJ, Bandyopadhyay S (2004) Optimization of extrusion process variables using a genetic algorithm. Trans IChemE C Food Bioprod Process 82(C2):143-150

33. Shankar JT, Sokhansanj S, Bandyopadhyay S, Bawa AS (2010) A case study on optimization of biomass flow during single-screw extrusion cooking using genetic algorithm (GA) and response surface methodology (RSM). Food Bioprocess Technol 3(4):498-510

34. Tumuluru JS, Sokhansanj S, Bandhopadhyay S, Bawa AS (2013) Changes in moisture, protein, and fat content of fish and rice flour coextrudates during single-screw extrusion cooking. Food Bioprocess Technol 6(2):403-415

35. Mani S, Tabil LG, Sokhansanj S (2006) Effects of compressive force, screen size and moisture content on mechanical properties of biomass pellets from grasses. Biomass Bioenergy 30(7):648-654
36. Mani S, Tabil LG, Sokhansanj S (2003) An overview of compaction of biomass grinds. Powder Handl Process 15(3):160-168

37. Hill B, Pulkinen DA (1988) A study of the factors affecting pellet durability and pelleting efficiency in the production of dehydrated alfalfa pellets. Saskatchewan Dehydrators Association, Saskatchewan

38. Kashaninejad M, Tabil LG (2011) Effect of microwave-chemical pretreatment on compression characteristics of biomass grinds. Biosyst Eng 108:36-45

39. Shaw MD, Tabil LG (2007) Compression and relaxation characteristics of selected biomass grinds. ASAE Annual International Meeting, Minneapolis, MN, June 17-20, 2007, Paper Number 076183, 2950 Niles Road, St. Joseph, MI 49085-9659 USA

40. Mani S, Tabil LG, Sokhansanj S (2002) Compaction behavior of some biomass grinds. AIC Paper No. 02-305. Saskatoon, Saskatchewan: AIC 2002 Meeting, CSAE/SCGR Program

41. Chancellor WJ (1962) Formation of hay wafers with impact loads. Agric Eng 43(3):136-138, 149

42. Gustafson AS, Kjelgaard WL (1963) Hay pellet geometry and stability. Agric Eng 44(8):442-445

43. Smith E, Probert S, Stokes R, Hansford R (1977) The briquetting of wheat straw. J Agric Eng Res 22:105-111

44. Al-Widyan MI, Al-Jalil HF, Abu-Zreig MM, Abu-Handeh NH (2002) Physical durability and stability of olive cake briquettes. Can Biosyst Eng 44:341-345

45. Mani S, Tabil LG, Sokhansanj S (2004) Grinding performance and physical properties of wheat and barley straws, corn stover, and switchgrass. Biomass Bioenergy 27:339-352

46. Box GEP, Hunter JS (1957) Multifactor experimental design for exploring responses. Ann Math Stat 28:192-242 